JAMP: Jurnal Adminitrasi dan Manajemen Pendidikan Volume 1 Nomor 2 Juni 2018, Hal :231-237

Tersedia Online di http://journal2.um.ac.id/index.php/jamp/ ISSN 2615-8574 (online)

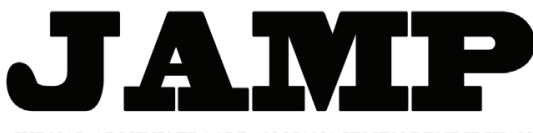

JURNAL ADMINISTRASI DAN MANAJEMEN PENDIDIKAN

\title{
PENGELOLAAN KEARSIPAN
}

\author{
Recki Ari Wijaya \\ Bambang Budi Wiyono \\ Ibrahim Bafada
}

\author{
reckiwijaya@gmail.com \\ Universitas Negeri Malang, Jl. Semarang No. 5 Malang 65145
}

\begin{abstract}
The purpose of this study is to determine the type of archive in SMA Negeri 3 Jombang; management of incoming and outgoing mail at SMA Negeri 3 Jombang; archive storage system in SMA Negeri 3 Jombang; archive storage procedure in SMA Negeri 3 Jombang; archive maintenance procedures in SMA Negeri 3 Jombang; and found efforts to overcome the depreciation or destruction of the archives in SMA Negeri 3 Jombang. This research uses qualitative method with case study research. The result of the research is the form of archives in the form of letters of work and other archives, management of outgoing and incoming mail in SMAN 3 Jombang by applying the agenda book, management or management of archives that change in the arrangement of archives, receive the archives and read it then record the archive in the agenda book, archives are stored in a place that is not damp and cleaned, overcoming the destruction or depreciation of the archives in SMAN 3 Jombang is by observing or observing the archive retention schedule.
\end{abstract}

Keywords: management, archive

Abstrak: : Tujuan penelitian ini yaitu untuk mengetahui jenis arsip yang ada di SMA Negeri 3 Jombang; pengelolaan surat masuk dan surat keluar di SMA Negeri 3 Jombang; sistem penyimpanan arsip di SMA Negeri 3 Jombang; prosedur penyimpanan arsip di SMA Negeri 3 Jombang; prosedur pemeliharaan arsip di SMA Negeri 3 Jombang; dan menemukan upaya untuk mengatasi penyusutan atau pemusnahan arsip di SMA Negeri 3 Jombang. Penelitian ini menggunakan metode kualitatif dengan jenis penelitian studi kasus. Hasil dari penelitian yang dilakukan yaitu bentuk arsip yang berupa surat-surat kerja dan arsip-arsip lainnya, manajemen surat keluar maupun masuk di SMAN 3 Jombang dengan menerapkan buku agenda, manajemen atau pengelolaan arsip yang berubah-ubah dalam penataan kearsipannya, menerima arsip dan membacanya kemudian mencatat arsip tersebut dalam buku agenda, arsip-arsip disimpan di tempat yang tidak lembab serta dibersihkan, mengatasi pemusnahan atau penyusutan arsip di SMAN 3 Jombang yaitu dengan memperhatikan atau mengamati pada jadwal retensi arsip.

Kata kunci: pengelolaan, arsip

Saat ini teknologi dan ilmu pengetahuan semakin berkembang pesat seiring dengan perkembangan zaman saat ini yang semakin cepat dan modern. Hal ini akan berpengaruh pada kemajuan suatu lembaga, baik lembaga pendidikan, lembaga pemerintahan maupun lembaga swasta. Setiap lembaga baik lembaga swasta maupun pemerintahan dan lembaga pendidikan tentu menginginkan dan membutuhkan administrasi yang baik dalam manajemen atau pengelolaan arsipnya. Berbagai cara dilakukan untuk pengelolaan arsip yang baik dalam setiap lembaga, mengarsip dokumen penting dalam.bentuk softfile maupun hardfile dilakukan tetapi tidak sepenuhnya tertata rapi, karena masih banyak ditemukan dokumen penting sulit ditemukan ketika dibutuhkan. Arsip.perlu dikelola dengan.baik dengan tujuan 
untuk membantu tugas lembaga dalam pencapaian tujuan. Jika kearsipan suatu lembaga tidak tertata rapi, maka pengawai atau karyawan lembaga kesulitan menemukan dokumen yang dibutuhkan dalam waktu yang singkat.

Undang-Undang.Nomor 43.Tahun 2009 menjelaskan bahwa pengertian arsip adalah "rekaman peristiwa atau kegiatan.yang diterima oleh lembaga negara, pemerintah daerah, perusahaan, organisasi politik, lembaga pendidikan, dan perseorangan untuk pelaksanaan.kehidupan bermasyarakat yang berupa berbagai bentuk dan media sosial dengan perkembangan komunikasi dan perkembangan teknologi informasi". Berdasarkan.pengertian arsip di atas diketahui bahwa arsip adalah naskah tertulis yang didalamnya memuat keterangan-keterangan penting. Arsip sangat berperan penting dalam suatu lembaga, yaitu sebagai penyajian informasi maupun pusat ingatan bagi seorang pimpinan untuk dapat merumuskan kebijakan dan membuat.keputusan, maka untuk dapat memberikan atau menyajikan informasi yang akurat dan lengkap harus memiliki prosedur tertentu dan sistem yang baik dalam pengelolaan.kerasipannya. Proses yang sedemikian tersebut dapat menciptakan arsip apapun jenisnya baik yang tekstual maupun non tekstual. Arsip inilah yang suatu saat akan.diberkaskan berdasarkan transaksi dan kegiatannya sesuai kepentingan unit kerja agar mudah dicari dan ditemukan kembali.

Hal inilah yang perlu dipahami oleh petugas kearsipan, pegawai, atau karyawan suatu lembaga atau.organisasi agar memperhatikan setiap pengelolaan dokumen-dokumen penting yang tertib dan teratur, sehingga arsip tersebut dapat digunakan seoptimal mungkin. Wursanto (2006:227).menyatakan "Kearsipan merupakan suatu kegiatan.yang berkaitan dengan.penerimaan , pencatatan, penyimpanan, penggunaan, pemusnahan dan penyusutan, pemeliharaan benda-benda arsip", dengan pengelolaan arsip, diharapkan setiap organisasi dan lembaga pendidikan dapat mengelola arsip dengan benar dan baik serta untuk melaksanakan tugas dan tanggung jawab dibutuhkan.perorangan. Wawancara yang dilakukan peneliti saat melakukan studi pendahuluan oleh ibu Tin tentang tata kearsipan di SMAN 3 Jombang, adalah sebagai berikut: "SMAN 3 Jombang menerapkan sistem pengelolaan arsip dinamis, dimana proses pengendalian kearsipannya dinamis secara efisien dan efektif, sistematis melalui penciptaan, pemeliharaan, penggunaan, serta penyusutan arsip dengan didukung SDM atau sumber daya manusia, sarana dan prasarana, serta sumber daya lainnya. Salah satu upaya untuk mendukung pengelolaannya adalah dengan mewujudkan sistem aplikasi kearsipan yang dapat di operasikan melalui jaringan komputer dan juga menggunakan.kombinasi antara beberapa sistem penyimpanan arsip yaitu kombinasi antara sistem nomer, sistem wilayah, sistem subjek, sistem semi.sentralisasi dengan menggunakan metode manual dalam penataan arsipnya, tetapi masih ada juga arsip yang ditumpuk didalam gudang karena.kurangnya personil dan ketenagaan yang memadai untuk mengurai pemusnahan atau penyusutan arsip yang tidak terpakai".

\section{METODE}

Penelitian ini menggunakan pendekatan kualitatif dengan jenis penelitian studi kasus karena penelitian ini memusatkan perhatian.pada suatu kasus yang unik secara intensif.dan rinci. Penelitian ini bermaksud untuk mengetahui secara mendalam kegiatan pengelolaan kearsipan di SMAN 3 Jombang dengan tujuan agar dapat membantu proses pengelolaan arsip yang ada di sekolah ini. Dalam penelitian ini sumber.data.primer diperoleh dengan melakukan wawancara kepada TU, data sekunder diperoleh melalui petugas kearsipan dan juga pihak sekretaris TU SMAN 3 Jombang. Penelitian ini pada pengumpulan datanya menggunakan teknik wawancara, dokumentasi, dan observasi. Analisis data dilakukan selama berada di lapangan, setelah selesai di lapangan, maupun sejak sebelum peneliti memasuki lapangan. Kegiatan analisis data bersamaan dengan pengumpulan data. Dalam analisis data, peneliti mereduksi data yang diperoleh melalui penelitian, lalu memilah setiap data sesuai fokus dan selanjutnya membuat kesimpulan pada masing-masing temuan fokus. Setelah analisis data dilakukan maka dilanjutkan dengan pemeriksaan keabsahan temuan informasi menggunakan teknik triangulasi (sumber, metode/teknik, dan waktu), pengecekan anggota, perpanjangan pengamatan, dan kecukupan bahan referensi. 


\section{HASIL}

Berdasarkan penelitian yang sudah dilakukan, hasil penelitian adalah sebagai berikut: a) Jenis arsip yang ada di SMAN 3 Jombang yaitu berbentuk surat-surat kerja dan arsip-arsip penting.lainnya. Arsip-arsip tersebut dikelompokkan berdasarkan perihal/subjek surat, baik itu surat keluar maupun surat masuk, sehingga dapat disimpulkan bahwa jenis-jenis arsip yang disimpan oleh SMAN 3 Jombang terdiri dari surat keluar.dan masuk. Dari jenis-jenis arsip tersebut sebagian besar atau yang paling banyak merupakan surat yang berasal dari dinas dan pengelompokannya berdasarkan subjek dan perihal surat. Pengelompokan tersebut tidak menjadi suatu masalah karena pelaksanaannya kegiatan.pengelolaan arsip dapat berjalan lancar, rapi, dan teratur; b) Pengelolaan surat.keluar maupun masuk di SMAN 3 Jombang berperan sangat penting baik pada sekolah atau lembaga swasta maupun pemerintah, dan SMAN 3 Jombang pengelolaan.surat yang keluar dan masuk berjalan dengan lancar karena adanya pencatatan dalam buku agenda. Penerapan buku agenda ini mengacu pada Standart.Operational.Procedur (SOP) SMAN 3 Jombang; c) Sistem penyimpanan arsip yang diterapkan di SMAN 3 Jombang adalah sistem pengelolaan arsip dinamis, sistem pengelolaan arsip dinamis yaitu proses pengendalian arsip yang berubah-ubah secara efektif dan efisien, sistematis melalui penciptaan, penggunaan, penyusutan arsip, dan pemeliharaan serta kombinasi antara beberapa sistem penyimpanan arsip yaitu antara sistem nomer, sitem wilayah, sitem subjek, dan sistem tanggal, memakai sistem semi.sentralisasi karena masih menggunakan metode kombinasi manual dan dinamis dalam penataan arsipnya; d) Prosedur penyimpanan arsip di SMAN 3 Jombang adalah menerima serta membaca arsip yang kemudian mencatat dalam buku agenda, setelah itu arsip disimpan sesuai pengeklarifikasiannya. Prosedur penyimpanan arsip yang diterapkan di SMAN 3 Jombang selama ini telah dilakukan dengan baik sehingga kearsipan berjalan lancar; e) Prosedur pemeliharaan arsip di di SMAN 3 Jombang dilakukan untuk.melindungi arsip dari kerusakan, arsip-arsip yang disimpan diletakkan/ditempatkan di tempat yang tidak lembab serta dibersihkan apabila banyak debu yang menempel. Arsip-arsip tersebut disimpan dalam map odner dan ditata secara rapi di lemari khusus arsip yang terbuat dari kayu supaya arsip tidak termakan oleh tikus atau serangga didalam lemari yang sudah ada kapur barusnya; f) Menemukan upaya. untuk mengatasi.pemusnahan atau penyusutan arsip di SMAN 3 Jombang adalah dengan mengamati maupun memperhatikan pada jadwal retensi arsip. Arsip yang sudah tidak dipakai akan disimpan di dalam gudang dahulu. Pemusnahan dan penyusutan dilaksanakan dengan pemusnahan berkas, pihak sekolah sebaiknya menyiapkan.prosedur atau langkah-langkah untuk menetapkan cara pemusnahan dan penyusutan yang paling sesuai. Pemilihan metode atau cara bisa menggunakan pertimbangan: jumlah volume, jenis ukuran, serta persentase dokumen inaktif yang bersifat rahasia yang akan dimusnahkan. Selain itu apabila bukan merupakan dokumen rahasia, perlu diperhatikan juga nilai.jual dari dokumen inaktif yang akan dimusnahkan. Serta bisa dibandingkan biaya pemusnahan secara mandiri dengan biaya pengggunaan jasa layanan pemusnahan. Umumnya sekolah mensyaratkan adanya berita acara tentang pemusnahan dokumen yang tergolong inaktif.

\section{PEMBAHASAN}

SMAN 3 Jombang menyimpan arsip yang sebagian besar berbentuk surat penting dan arsiparsip penting lainnya yang dikelompokkan berdasarkan perihal atau subjek surat, baik itu surat keluar ataupun masuk. Pengelompokan arsip berdasarkan subjek surat yang diterapkan di SMAN 3 Jombang sudah sesuai dengan pendapat Amsyah (2001:148) yang mengungkapkan bahwa sistem subjek adalah sistem penataan berkas atau naskah tertulis berdasarkan kegiatan yang berhubungan dengan perusahaan yang menggunakan sistem ini. Menurut Sedermayanti (2007:71) arsip atau dokumen yang diperlukan sebagai sarana informasi dan bukti secara dalam penyelenggaraan administrasi. Kearsipan yang teratur diperlukan untuk kelancaran administrasi dalam suatu lembaga. Kearsipan digunakan sebagai informasi atau rekaman kegiatan, arsip digunakan sewaktu-waktu diperlukan untuk kepentingan administrasi maupun keperluan lain harus dapat ditemukan dengan cepat, tepat dan lengkap (Ermawaty, 2013).

Zulkarnain dan Sumarsono (2015:209) menyatakan, manajemen kearsipan adalah pelaksanaan fungsi-fungsi manajemen dalam rangka mengelola keseluruhan daur hidup arsip (life cycle of a records) 
yang terdiri dari fase: penciptaan dan penerimaan (creation and receipt); pendistribusian (distribution); penggunaan (use); pemeliharaan (maintenance) dan penyusutan (disposition) suatu arsip. Setiap fase di dalam daur hidup arsip ini merupakan sub asas yang akan mempengaruhi sub asas yang lain. Jadi dengan kata lain tata kearsipan merupakan suatu proses kegiatan mulai dari penerimaan, pengumpulan, pengaturan, pemeliharaan, dan penyimpanan dokumen menurut sistem tertentu, sehingga saat diperlukan dapat ditemukan dengan cepat dan mudah.

Menurut Ramanda dan Indrahti (2015: 2) pengelolaan arsip harus memperhatikan sistem yang paling sesuai dengan keadaan suatu instansi, dengan penataan arsip yang tepat akan memudahkan dalam penemuan kembali arsip. Arsip dapat berubah status sesuai dengan perjalanan status bergerak mundur, tidak arah sebaliknya, sehingga tidak hanya terbatas pada satu klasifikasi saja. Informasi yang terekam merupakan darah kehidupan bagi organisasi karena segala aktivitas kantor atau lembaga, baik pemerintah atau bisnis, membutuhkan informasi. Selanjutnya jika ditinjau dari sudut perundang-undangan, maka arsip terdapat dua jenis yaitu arsip otentik dan tidak otentik. Menurut Sukoco (2007:21) arsip.otentik tercantum.tanda tangan sah beserta tinta sebagai tanda keabsahan isi arsip. Sedangkan arsip tidak otentik tidak adanya tanda tangan sah beserta tinta diatas arsip. Berdasarkan paparan data dan teori, disimpulkan bahwa jenis arsip yang ada di SMAN 3 Jombang terdiri dari surat keluar dan keluar, sebagian besar surat-surat tersebut adalah surat dinas yang pengelompokannya berdasarkan subjek dan perihal surat. Pengelompokan surat tidak menjadi suatu masalah karena pelaksanaannya kegiatan.pengelolaan arsip dapat berjalan lancar, rapi, dan teratur.

Pengelolaan surat keluar dan surat masuk di SMAN 3 Jombang menerapkan buku agenda. Penerapan ini sitem buku agenda mengacu pada Standar Operasional Prosedur (SOP) SMAN 3 Jombang. Pengelolaan surat yang keluar maupun masuk merupakan hal yang sangat penting terhadap kelangsungan proses surat keluar dan surat masuk agar tidak terjadi kerancuan tata kearsipan. Penulisan di dalam buku agenda dapat dilakukan secara efisien dan efektif dalam menekan kerancuan surat menyurat di SMAN 3 Jombang. Surat sebagai media komunikasi yang memiliki kelebihan tersendiri jika dibandingkan dengan media komunikasi lainnya. Komunikasi melalui surat memberikan keleluasaan dan kesempatan lebih luas kepada pencipta surat untuk berfikir dan merenungkan hal-hal yang disampaikan. Buruk maupun baiknya saran, pendapat, ataupun penjelasan, dapat dipertimbangkan dengan seksama, sehingga untuk dapat mengkomunikasikan sesuati dengan baik melalui surat, maka diperlukan persiapan matang, akurat, keputusan bijak, serta pilihan kata atau kalimat yang tepat digunakan. Berdasarkan paparan data dan teori yang ada diatas diketahui bahwa surat berperan sangat penting dalam urusan sekolah, baik itu pada sekolah atau lembaga swasta atau pemerintah, di SMAN 3 Jombang surat keluar maupun masuk semuanya dapat berjalan lancar karena dengan adannya pencatatan dalam buku agenda.

Dalam pekerjaan kantor maupun lembaga kearsipan merupakan bagian yang sangat penting, yaitu menjadi sumber informasi, sebagai pusat kegiatan suatu kantor, dan sebagai ingatan kantor, sehingga perlu suatu sistem penyimpanan yang baik dan benar tetapi mudah ditemukan kembali pada saat dibutuhkan. Sistem penyimpanan arsip atau filling system adalah kegiatan menyusun dan mengatur arsip secara sistematis dan logis dengan merawat dan menyimpannya untuk digunakan secara ekonomis.dan. aman (Sedarmayanti 2003: 114). Hal tersebut juga diungkapkan Sugiarto (2005: 51) sistem penyimpanan adalah.sistem yang digunakan untuk menyimpan dokumen yang sudah disimpan dengan menciptakan dan menemukan dokumen dengan cepat ketika dokumen diperlukan sewaktu-waktu. Untuk mempermudah dalam menemukan kembali arsip jika diperlukan sewaktu-waktu maka diperlukan sistem penyimpanan arsip yang tepat dan sesuai dengan kebutuhan instansi atau organisasi. Berdasarkan paparan data dan teori diatas sistem penyimpanan di SMAN 3 Jombang adalah kombinasi. Penerapan sistem kombinasi beberapa sistem penyimpanan ini telah dapat memudahkan dan membantu kegiatan administrasi. Jadi apabila prosedur dalam penyimpanan arsip yang sudah digunakan sesuai dengan teori yang ada, maka tidak membutuhkan waktu yang lama untuk menemukan kembali. Langkah-langkah atau prosedur penyimpanan arsip bertujuan mempermudah petugas untuk menata/menyimpan dan menemukan kembali arsip jika sewaktu-waktu dibutuhkan, dengan adanya prosedur tersebut diharapkan kegiatan kearsipan di SMAN 3 Jombang berjalan dengan tertib dan teratur. Sistem penyimpanan dan penataan arsip juga diperlukan untuk memudahkan penemuan kembali dan juga penyimpanan surat (Sedarmayanti, 
2003:70). Berdasarkan.paparan data data dan teori diatas adapun prosedur atau langkah-langkah adalah membaca arsip yang sudah disimpan, mencatat dalam buku agenda, kemudian menyimpan arsip sesuai klasifikasi. Prosedur penyimpanan arsip yang telah diterapkan di SMAN 3 Jombang selama ini telah dilaksanakan dengan baik sehingga kearsipan berjalan lancar.

Pemeliharan arsip sangat penting dilakukan secara rutin karena untuk menjaga arsip agar tidak cepat rusak. Kondisi lingkungan disekitar tempat penyimpanan dan ruang kearsipan juga berpengaruh dalam menjaga keutuhan arsip. SMAN 3 Jombang juga melakukan pemeliharaan arsip, meskipun cara pemeliharaannya sederhana. Adapun cara yang dilakukan yaitu selalu memperhatikan tata letak penyimpanan arsip serta membersihkannya apabila banyak debu yang menempel, arsip-arsip ditata secara rapi guna untuk memudahkan ketika membersihkannya, tidak hanya itu, lemari arsip juga rutin diberi kapur barus didalam untuk menghindari gangguan tikus atau serangga. Sirkulasi udara dan pencahayaan diruang penyimpanan juga diperhatikan agar ruangan tidak pengap dan lembab. Sesuai dengan pendapat Sedarmayanti (2003:110-113), cara pemeliharaan arsip sebagai berikut: a) Pengaturan ruangan, ruangan harus tetap dijaga agar tetap kering, terang, mempunyai ventilasi merata dan terhindar dari kemungkinan serangan air, serangga, api, sebagainya; b) Tempat penyimpanan arsip hendaknya diatur berjarak atau renggang agar ada udara di antara berkas yang disimpan; c) Penggunaan bahanbahan pencegah rusaknya arsip, salah satunya adalah meletakkan kapur barus ditempat penyimpanan atau dengan menyemprotkan bahan kimia secara berkala; d) Larangan membawa makanan dan merokok ditempat penyimpanan arsip; e) Arsip selalu dibersihkan dan dijaga dari noda karat dan lain-lainnya.

Jumlah arsip di unit arsip semi sentral dan unit-unit kerja selalu mengalami perkembangan menjadi banyak. Semakin banyak kegiatan sekolah, maka semakin cepat pula bertambahnya berkas dan arsip, dan tidak selamanya arsip akan terus berada di dalam tempat pennyimpanan. Untuk menghadapi masalah itu diperlukannya adanya pemusnahan dan penyusutan arsip. Penyusutan arsip juga dimaksudkan sebagai usaha untuk mencegah.kesalahan dalam penyusutan arsip, jangan sampai warkat yang masih bernilai guna seharusnya tetap disimpan justru dimusnahkan. Penyusutan arsip di SMAN 3 Jombang telah ditetapkan setiap tahun secara rutin dengan mengacu kepada jadwal retensi arsip. Jadwal retensi arsip merupakan suatu daftar yang berisi jenis arsip beserta jangka waktu penyimpanannya dengan keterangan simpan permanen, musnah, atau dinilai kembali. Penyusutan dengan jadwal retensi arsip hendaknya tidak lepas dari tindakan menilai suatu arsip baik atas dasar jenis fisiknya maupun jenisnya informasinya. Di SMAN 3 Jombang penyusutan arsip dilakukan dalam jangka waktu antara 1-2 tahun misalnya seperti surat undangan waktunya 1 tahun sudah ditarik untuk dimusnahkan. Pemusnahan arsip ini dilakukan menggunakan mesin penghancur kertas atau bisa juga dengan cara dibakar, sesuai dengan cara pemusnahan menurut Sukoco (2007:101) penyusutan arsip dilakukan dengan cara pencacahan, dibakar, menggunakan bahan kimia dan pembuburan. Pemusnahan arsip ini berdasarkan jadwal retensi arsip dan berdasarkan nilai guna arsip. Sebelum dimusnahkan, arsip dinilai terlebih dahulu atau diseleksi apakah arsip tersebut masih layak untuk dipakai atau tidak pinya nilai guna lagi. Setelah itu hasil penelitian itu dimintakan persetujuan kepada kepala sekolah dan membuatkan berita acara tentang pemusnahan arsip. Sesuai dengan pendapat Amsyah (2001: 218), pedoman yang dijadikan.dasar seleksi adalah.jadwal retensi. Langkah-langkah penyusutan umumnya terdiri dari: seleksi, pembuatan daftar jenis arsip yang dimusnahkan, pembuatan berita acara pemusnahan dan, pelaksanaan pemusnahan dengan disertai dengan saksi-saksi.

Berdasarkan paparan data dan teori diatas pemusnahan dilakukan dengan pemusnahan berkas. Pihak sekolah sebaiknya menyiapkan dan membuat langkah-langkah untuk menetapkan cara pemusnahan yang paling sesuai. Pemilihan cara tersebut bisa menggunakan pertimbangan: jumlah volume, jenis ukuran, serta persentase dokumen inaktif yang bersifat rahasia. Selain itu apabila bukan merupakan dokumen rahasia perlu diperhatikan juga nilai jual dari dokumen inaktif yang akan dimusnahkan. Serta bisa dibandingkan biaya pemusnahan secara mandiri dengan biaya pengggunaan jasa layanan pemusnahan. Umumnya sekolah mensyaratkan adanya berita acara berkaitan dengan penyusutan arsip yang tergolong inaktif. 


\section{KESIMPULAN DAN SARAN}

\section{Kesimpulan}

Kesimpulan dari hasil penelitian ini sebagai berikut: Sebagain besar arsip yang disimpan oleh SMAN 3 Jombang adalah berbentuk arsip-arsip penting dan surat penting lainnya. Arsip-arsip tersebut dikelompokkan menurut perihal atau subjek surat, baik surat keluar maupun surat yang masuk. Jenis arsip yang disimpan di SMAN 3 Jombang terdiri dari Ijazah/SKHUN, surat yang masuk maupun surat yang keluar. Surat yang ada kebanyakan atau sebagian besar merupakan surat dari dinas pendidikan. Pengelompokan tersebut tidak menjadi suatu masalah karena pelaksanaan kegiatan pengelolaan arsip dapat berjalan secara rapi dan teratur di SMAN 3 Jombang.

Pengelolaan surat yang keluar dan yang masuk di SMAN 3 Jombang dengan diterapkannya buku agenda. Penerapan sistem buku agenda mengacu pada Standar Operasional Prosedur (SOP) SMAN 3 Jombang. Pengelolaan surat yang keluar maupun masuk ini merupakan hal yang sangat penting bagi kelangsungan proses pengelilaan surat agar tidak terjadi kerancuan tata kearsipan.

Adapun sistem penyimpanan di SMAN 3 Jombang adalah kombinasi antara beberapa sistem penyimpanan arsip yaitu kombinasi antara sistem nomor, sistem subjek, dan sistem tanggal serta penyimpanan dengan komputer. Arsip-arsip yang disimpan, digunakan kembali jika diperlukan, maka penyimpanan arsip harus dalam penataan yang rapi dan mudah untuk ditemukan kembali jika sewaktuwaktu dibutuhkan. Penerapan kombinasi beberapa sistem penyimpanan ini telah dapat memudahkan dan membantu kegiatan administrasi. Adapun prosedur penyimpanan arsip di SMAN 3 Jombang yaitu menerima arsip serta membaca arsip yang disimpan, dan kemudian mencatat arsip tersebut dalam buku agenda, setelah itu memyimpan arsip sesuai pengklasifikasinya. Prosedur penyimpanan arsip yang diterapkan di SMA N 3 Jombang selama ini telah dilaksanakan dengan benar dan baik jadi kearsipan berjalan secara lancar.

SMAN 3 Jombang juga melakukan pemeliharaan arsip. Adapun cara yang dilakukan yaitu selalu memperhatikan tata letak penyimpanan arsip serta membersihkannya. Arsip akan disimpan sesuai dengan perihal surat dengan langkah-langkah seperti menerima surat dan membaca isi surat keseluruhan yang akan disimpan, mencatat ke buku agenda surat, dan menyimpan arsip sesuai pengklasifikasiannya. Arsiparsip ditata secara rapi dengan tujuan memudahkan untuk membersihkannya. Lalu untuk menghindri gangguan tikus maupun serangga, sekolah memberikan kapur barus di dalam lemari penyimpanan arsip.

Pemusnahan arsip ini berdasarkan jadwal retensi arsip dan berdasarkan nilai guna arsip. Arsip yang dimusnahkan tersebut dinilai terlebih dahulu atau diseleksi apakah arsip itu masih layak dipakai atau sudah tidak punya nilai guna lagi dan dilakukan setiap tahun secara rutin dengan mengacu kepada jadwal retensi arsip. Jadwal retensi arsip merupakan suatu daftar yang di dalamnya berisi tentang jenisjenis arsip beserta jangka waktu.penyimpanannya dengan keterangan simpan permanen, musnah atau dinilai kembali.

\section{Saran}

Berdasarkan kesimpulan di atas terdapat beberapa saran untuk penelitian selanjutnya yang relevan dengan subjek penelitian ini: 1) Kepala Sekolah SMA Negeri 3 Jombang, hasil penelitian ini digunakan sebagai untuk lebih inovatif dan kreatif dalam menciptakan pengelolaan arsip dan dapat dijadikan sebagai referensi tambahan dalam melakukan pengelolaan atau manajemen arsip yang berkualitas dalam tata pengelolaan arsip yang ada di SMA Negeri 3 Jombang ; 2) Petugas Arsiparis SMA Negeri 3 Jombang, hasil penelitian ini sebagai bahan saran juga masukan bagi Arsiparis agar lebih dinamis dalam tata kelola arsip di SMA Negeri 3 Jombang serta dapat dijadikan acuan dalam pengelolaan kearsipan di sekolah secara lebih inovatif berkaitan dengan proses pengelolaan kearsipan; 3) Ketua Jurusan Administrasi Pendidikan, hasil penelitian ini bermanfaat untuk menambah pengetahuan tentang pengelolaan kearsipan yang diharapkan dapat dijadikan referensi tambahan dan sebagai rujukan oleh ketua jurusan dalam menjalankan tugas perkuliahan yang berkaitan dengan pengelolaan kearsipan dan juga manajemen pendidikan di sekolah; 4) Peneliti lain, penelitian ini sebagai bahan referensi untuk mengembangkan penelitian selanjutnya lebih detail serta mendalam berdasarkan penelitian yang telah dilakukan dengan topik dan tema yang sejenis. 


\section{DAFTAR RUJUKAN}

Amsyah, Z. 2001. Manajemen Kearsipan. Jakarta: PT. Gramedia Pustaka Utama.

Ermawaty. 2013. Pengelolaan Manajemen Kearsipan di Perguruan Tinggi. Jurnal Tabularasa PPS UNIMED, 10(2), 141-150. Dari https://www.google.com/url?sa=t\&rct=j\&q=\&esrc=s\&source=web\&cd=4\&ved=0ah UKEwjYkYTkpY7bAhWKXSsKHRLjDM0QFgg7MAM\&url=http\%3A\%2F\%2Fdownload.portalgaruda. org\%2Farticle.php\%3Farticle\%3D413478\%26val\%3D5732\%26title\%3DPENGELOLAAN\%2520MANAJ EMEN\%2520KEARSIPAN\%2520\%2520DI\%2520PERGURUAN\%2520TINGGI\&usg=AOvVaw312UHS bkPVdYBcmcZk1vfm.

Ramanda, R. S \& Indrahti. S. 2015. Analisis Pengelolaan Arsip Inaktif Terhadap Temu Kembali Arsip di Pusat Arsip (Record Center) Politeknik Negeri Semarang. Jurnal Ilmu Perpustakaan, 4(3), 1-10. Dari https://media. neliti.com/media/publications/137066-ID-none.pdf.

Sedarmayanti. 2003. Tata Kearsipan Dengan Memanfaatkan Teknologi Modern. Bandung: Mandar Maju.

Sugiarto, A.W. T. 2005. Manajemen Kearsipan Modern dari Konvensional ke Basis Komputer. Yogyakarta: Gava Media.

Sukoco, B. M. 2007. Manajemen Administrasi Perkantoran Modern. Jakarta: Erlangga.

Wursanto. I. 2006. Kompetensi Sekretaris. Yogyakarta: Penerbit Andi.

Zulkarnain, W. \& Sumarsono, R. B. 2015. Manajemen Perkantoran Profesional. Malang: Gunung Samudra. 